IIUC STUDIES

ISSN 1813-7733

Vol.- 9, December 2012

(p 17-38)

\title{
Towards an Integrated Islamic Curriculum for Bangladesh in line with the Recommendations of OIC Conference'77
}

\author{
Prof. Dr. Abu Bakr Rafique*
}

\begin{abstract}
Education holds very high position in Islam, the $1^{\text {st }}$ revelation to the Prophet (s.a.w.) contains especial emphasis on knowledge and has been identified as an especial favour of the Creator. The four point objectives behind sending the Prophet Muhammad (s.a.w) with the mission of prophethood are all related to recitation, teaching and purification of soul through continuous training and guidance. Seeking knowledge has been made an obligatory duty on every Muslim - male and female - by the Prophet (s.a.w.). The Muslim wherever had ruled they had patronized education and established educational Institutions. These were open to all the peoples regardless of race, religion and caste. The Muslim rulers who ruled Bengal for more than 500 years had established many educational institutions, introduced a very advanced education system in Bengal, which was Islamic in nature and an integrated policy based on Arabic and Persian. After the British took over the rule of Bengal from the hands of the Muslims, they introduced an English medium secular education policy replacing the prevailing education system introduced by the Muslims. But the majority of the Muslims could not accept that policy, knowing that the main objective behind introducing that policy was degrading the Muslim society. The paper is a historical overview of prevailing Curriculum of the Islamic Education System in Bengal and the then East Pakistan in general, and the present Bangaldesh in particular in one hand, and a recommendation for introducing an integrated Islalmic Education Policy on the other.
\end{abstract}

Keywords: Integrated, Curriculum, Patronize, Recommendations

\footnotetext{
* Pro Vice-Chancellor, International Islamic University Chittagong, Bangladesh.
} 


\section{Introduction}

Islam has given prime importance to education. The first revelation of the Holy Qur'an contains proclamation about reading in the name of the Creator who is Compassionate enough to teach the mankind with the help of the pen, and to teach them whatever they knew not. The most important four point programs of prophet Muhammad (S.A.W.) for which he was sent down were all related to teaching and educating the people. (2) The Holy Prophet (S.A.W.) used to feel honoured to say that he was sent as a teacher. The Prophet (S.A.W.) had instructed all the Muslims, male and female, to seek knowledge. Due to all these reasons, seeking and imparting knowledge has always been considered as an act of 'Ibadah in the eye of Islam. Wherever the Muslims had gone, they had tried to disseminate knowledge and wherever they had ruled over the people they had patronized education, established educational institutions and introduced regular stipends for the scholars and researchers. This was the reason that almost all of the capitals of Muslim countries and the prominent cities were considered as the meeting place of the scholars of different religions, the poets, the philosophers, the chemists, the physicists, the writers and the litterateurs.

Almost all of the Muslim rulers had played their vital role in imparting education to the people in general and the Muslims in particular. The impact of this effort can be estimated from a report of Max Muller who mentioned that there were not less than 80,000 schools in Bengal alone in 1757, while the East India Company had took over the power through conspiracy by defeating Sirajuddawlah, the Nawab of Bengal. And according to Sir John Adams, the number of schools in Bengal and Bihar was not less than 100,000. (3)

The government used to grant settlement of land and the ameers and the wealthy persons used to make endowment (WAQF) in the name of different institutions to meet the expenses of these Religious Schools.

History has preserved the names of many Muslim Sultans of India as great patrons of education and scholarship. Some of them, whose contributions were worth mentioning are as follows:

Sultan Iltutmish (d. 1236 C.E.)

His daughter, Sultana Razia

His youngest son Nasiruddin Muhammad Shah (d. 1266 C.E.)

Sultan Ghiyasuddin Balban (d. 1286 C.E.)

Sultan Jalaluddin Khalji (d. 1296) 
Sultan Alauddin Khalji

Sultan Ghiyasuddin Tughlaq, the founder of Tughlaqese dynasty

Sultan Muhammad Tughlaq (d. 1351 C.E.)

Sultan Firoz Shah Tughlaq (d. 1388 C.E.)

Contributions of these rulers to the development of education and scholarship were remarkable.

Most of the rulers of Mughal dynasty in India like Zahiruddin Babar (1531 C.E.), Nasiruddin Humayun (d. 1556 C.E.), the King Jahangir (d. 1625 C.E.), King Shah Jahan (d. 1658 C.E.), King Awrangzeb (d. 1707 C.E.) and others were themselves great scholars and patrons of education.(8) Even Sher Shah Suri, who ruled Delhi for a short span of five years had established many Madrasahs and other educational institutions here and there in the country and made arrangements to meet the expenses of these institutions.(9)

The Nature and Curriculum of Religious Schools:

The religious schools were classified into three types:

\section{a) Maktab or Primary school:}

Here the curriculum was mainly related with how to recite the Qur'an correctly and giving primary knowledge of Persian language.

These maktabs were open to all citizens and these were spread over at every nook and corner of the country. Each and every mosque was also considered a Maktab, where the children of that particular locality used to be attached with, no special furniture was to be used, other than mats in these maktabs.

\section{b) Persian Schools:}

As Persian was the official language during the whole period of Muslim rule in India and Bengal, Persian was the medium of instruction in all secondary level schools. The books were also written in Persian. However, there was no separate Board or Directorate of education to look after the education policy and curriculum of these schools. The Head of the institution had full autonomy to determine the curricula and syllabi in these schools.(10) The subjects taught in these schools were (i) Persian language and Literature, (ii) Fiqh, (iii) Ethics, (iv) Mathematics, (v) Calligraphy, (vi) Essay writing etc.

\section{c) Arabic Madrasahs:}

The Arabic Madrasahs were considered as the seats of higher education. 
Though there was no central body for coordinations these institutions planning the courses and curricula of these Madrasahs but these madrasahs were characterized with following an integrated curriculum which includes courses on (i) Arabic Grammar, (ii) Arabic Literature, (iii) Fiqh, (iv) Usul-al-Fiqh, (v) Tafsir, (vi) Hadith, (vii) Ilmul Kalam, and (viii) Tasawwuf or instructions related to Sufis of India, being an adjacent country to Iran was influenced by the popularity of philosophy and gradually has made its important position in the curriculum also. The influence of philosophy is clearly seen in the education system introduced by Mulla Nizamuddin (1747 C.E.) which was accepted as a preferred education policy by the padagogists of the Indian subcontinent and which is still being followed by a large number of educational institutes known as the institutes of Dars-e-Nizami.(11)

The remarkable characteristic of this education system is that it is a relatively comprehensive policy which includes a curriculum related to spiritual and mundane knowledge. The graduates of these madrasahs were eligible enough to be employed in various responsible positions of public administration, Judicial services and also in religious institutions. The products of this system were used to prevail as prominent until the advent of British colonialists in Indian subcontinent.(12) William Hunter, the writer of "Indian Mussalmans", has acknowledged this in his book, as he mentions that the Muslims were superior not only in politics but also in knowledge and thought. They had an education policy which though inferior to that of ours as observed by A.C. Belly, but can never be considered a useless. It was established on solid foundation. No doubt it was the best possible system in consideration of the requirement of those days. This system had given them the superiority in education and politics.(13) The most remarkable characteristic of this education policy is that the education from primary to higher level was completely free of cost. And as such, each and every one who wanted to get his children educated upto the highest level could avail this facility without any financial burden.

In spite of all these positive characteristics as mentioned above, the education policy had some weaknesses, for which it can be criticized as follows: The books on Tafsir and Hadith were not sufficient. Only some parts of the Holy Qur'an and some selected Hadiths were included in the syllabus, whereas the greatest importance should have been given on these two main sources of Islam.

The books related to history, Geography and Arabic Literature were 
very few, whereas they are considered the most important areas of discipline related to Social and human science. Though books on Rhetoric are included in the curricula, proper importance has not been given on Arabic Literature, which was essential to understand Rhetoric.(14) It is also observed that the importance of philosophy was given more than it was required, specially the philosophy was developed either in line with Greek philosophy or to discard it, in both cases it was meaningless after the Greek philosophy was no longer prevailing in the world as a living philosophy.

\section{Education in Bengal during the British Regime:}

A glance at the official report of East India Company during their rule in Bengal reveals that the position of education in Bengal was far better compared to any other provinces of India. Max Muller, a British officer has estimated in the report of his study that the number of Madrasahs in Bengal during the inception of the British regime was 80,000. (1) Though most of these Madrasahs were run by the individual scholars at home, it indicates to a very flourishing situation of education during the Muslim rule in Bengal. A report mentions that the ratio of the students, with the number of population was 1:73. If the average number of students in each Madrasash was 0, then the total number of students was not less than 800,000 (eight hundred thousand). From the very beginning of British rule, the East India Company tried to destroy the education system of the Muslims. They had adopted some policies with this end in view. For example:

a. To confiscate the property owned by the educational institutions established by the Muslims.

b. Not to provide Financial support to Islamic educational institutions.

c. To close the doors of public services for the graduates of Islamic educational institutions.

d. On the other hand, they had established many English medium missionary schools here and there under the supervision of Churches. However it is very important to mention that the British colonialists had to wait as long as 78 years for introducing an independent education policy of their own. Lord Macklay was the engineer of that education policy. Regarding the objective of that policy, he is reported to have mentioned:

["We are going to introduce an education policy of ours, after getting educated under this policy a person though 
an Indian in colour and caste, but shall be considered a British in culture civilization and custom”.(15)]

The Muslims who had been a ruling class in India for more than five centuries could not accept this new education policy, especially after knowing the objectives of the British to degrade them socially and to deviate them culturally. The Hindus, on the other hand, had accepted this policy with great enthusiasm and got the opportunity of getting educated under this system and being appointed to different important positions of civil services.

The nature of this curriculum was secular, without having any scope for studying religion. Rather in many schools the students were compelled to study Christianity. As a result many Hindu students became Christians and were rewarded with big posts and high positions of administrative and executive services. However some of the Muslim thinkers later on tried to attract the Muslims to learn English and called them upon for getting modern education. Sir Syed Ahmad was the pioneer of that movement. He had established an English medium college at Aligarh, U.P. in 1864 called Mohammedan Oriental College, Aligarh. Later on it became a university known as Aligarh Muslim University. Another attempt was taken by Moulana Qasem Nanatwi in 1867 to establish a higher Islamic University at Deoband to save the Muslims from religious decadence. The curriculum of this institution was based on the Dars-e-Nizami, with much emphasis on Tafsir, Hadith and Fiqh, giving less importance to Philosophy. But teaching of English was totally avoided in this system. Many madrasahs were established throughout the country on this model which had played an important role to save the Muslims from religious and cultural deviations. Though they could do nothing for the enhancement of social and economical status of the Muslim masses, but one striking characteristic of this system is that, the Ulama who got educated under this system did never accept the British rule in India and they had pioneered the independence movement against British colonialism.

It is to be mentioned that one religious madrasah was established in Calcutta in 1781 by the British government in response to the demand of the Muslims, which was just to prove that they were not antagonistic towards Islam and the Muslims. The curriculum of this madrasah was a bit different from that of Deoband, due to inclusion of Logic and Philosophy as compulsory subjects and English and Mathematics as elective courses. 
This system could not get much popularity until the independence of India from British regime. However after the British had left the country, the curriculum of Aliah system got more popularity and government patronage for being comparatively modern and for coping up more with the requirements of the nation and demand of the day. But this education policy did not receive proper attention and due patronage of the government during the regime of Pakistan compared to that of the general Education system which was more or less a continuation of the secular education policy adopted by the British.

The Curriculum and Status of Religious Education during Pakistan and Aftermath:

The following education systems were existing in Bengal (the then East Pakistan) during the Pakistan regime.

\section{a) Government approved Madrasah education:}

This system was called Aliah system. It was a 15 years long education system prevailing in the country from the independence of Pakistan till today. Theis system was divided as following stages:

From 1947 upto 1983:

\begin{tabular}{|l|c|}
\hline Ibtidai' (Pre-Primary) & 3 years \\
\hline Dakhil (Primary) & 6 years \\
\hline Alim (Lower Secondary) & 2 years \\
\hline Fadhil (Secondary) & 2 years \\
\hline Kamil (Higher Secondary but with no approval) & 2 years \\
\hline Total & $\begin{array}{c}\mathbf{1 5} \\
\text { Years }\end{array}$ \\
\hline
\end{tabular}

From 1983 till today

\begin{tabular}{|l|l|}
\hline Dakhil: class 1-5 (Primary) & 5 years \\
\hline Dakhil: class 6-10 (Secondary) & 5 years \\
\hline Alim: class $11-12$ (H. Secondary) & 2 years \\
\hline Fadhil: class 13 -14 (No equivalence) & 2 years \\
\hline Kamil: class 15 -16 (No equivalence) & 2 years \\
\hline Total & $\mathbf{1 6}$ Years \\
\hline
\end{tabular}




\section{Equivalence:}

Upto 1963, no equivalence was made. However, a student could sit for special Examination of English \& Mathematics for obtaining equivalence of Secondary School Certificate (SSC). From 1963 to 1978, Fadhil was considered equivalent to Secondary and Kamil was left without any equivalence. From 1978 to 1983, Alim was considered equivalent to Secondary and Fadhil was equivalent to Higher Secondary. From 1983 till today Dakhil has been considered equivalent to Secondary. Alim has been considered equivalent to Higher Secondary, but Fadhil and Kamil were left without any equivalence.(according to a decision taken in the year 2005 Fadil has been accepted as aquivalent to degree and Kamil as aquivalent to Master degree, but not implemented till now)

\section{b) Non-Government Religious Institutions (Qawmi Madrasah):}

These institutions are known as the Qawmi Madrasahs. They follow a curriculum similar to that of Deoband Madrasah system. This system is based mainly upon studying text books on different subjects like Arabic Grammar and Literature, Fiqh \& Usul al- Fiqh, Balaghal \& Mantiq, Tafsir and Hadith, Urdu, Persian Literature and so on. Here the duration is not important but studying of the books included in the syllabus is more important. Hence a student if he is a meritorious one, can finish his study within eight years of schooling, whereas another student may take ten to twelve years for the same if he is a mediocre student or of dull merit.

The curriculum of the above mentioned two types of Madarasahs: The curriculum of government approved religious schools (Madrasahs) in Bangladesh is as follows: (16)

\section{Primary Level (5 years)}

The curriculum of this level includes:

i. National Language: Bangla. It is taught in all classes of Primary with a gradually improved syllabus.

ii. Arabic Language: Arabic is also taught in all classes of this level with an objective to enable the students to recite the Qur'an with correct pronunciation and to give them the knowledge of basic vocabulary and easy sentences.

iii. Arabic Grammar: Some books on basic grammar of Arabic are included in the curriculum of this level. 
iv. Aqaid and Fiqh: It starts with oral classes at the early stage and gradually some basic books are taught which include idea about Tawhid, Rishalah and Akhirah, the revealed books, the angels and also includes lessons on Tahara, Salat, Sawm, Zakat and Hajj and basic idea about some Muamalat.

v. English: It is also taught from class I, starting with Alphabets, easy vocabulary, practices on writing (seen and unseen), framing easy sentences, reading independently and developing understanding skill upto the meaning of the easy texts.

vi. English Grammar: It starts from class V, to give the students an idea about the basic grammatical rules of the language.

vii. Mathematics: It starts from the class I, starting from introducing the students with numericals and developing gradually to enable them doing basic with arithmetics independently.

viii. Social Sciences: It starts from class II, and contains in all classes of Primary level. The objective is to make the students aware about the basic concept of family, society, the state and government, basic administration system of a country etc.

ix. General Science: It starts teaching from class IV.

X. Environment Science: It starts teaching from class III.

xi. Geography: It starts teaching from class V.

xii. Physical Training: It starts from KG and continuous upto the end of Primary Level.

\section{Secondary Level (5 years) [This is known as Dakhil]}

The curriculum of this level includes the following courses:

i. Arabic: Arabic is taught in all the classes of this stage as a language and literature, but it is completely based on the text. No oral practices are done to develop the language skills of the students.

ii. Arabic Grammar: This is also taught in all classes of this level, but the approach is not scientific. The students are targeted to make them understand the rules and regulations related to grammar. In some cases they are encouraged to memorize some books on Grammar. 
iii. Al-Qur'an: It starts with translation of the Holy Qur`an beginning from class IX with teaching the students, the translation of Suratul Fatiha, Al-Baqara and Al-'Imran with some explanation.

iv. Hadith: Some selected Hadiths are also taught with translation in class IX and X.

v. Fiqh: It is taught as a compulsory subject in all classes of this level.

vi. Usual al Fiqh: It starts from class IX.

vii. Bangla: Compulsory in all classes.

viii. Bangla Grammar: Compulsory in all classes of this level.

ix. English Literature: Compulsory in all classes of this level.

x. English Grammar: Compulsory in all classes of this level, but teaching of Grammar is done in traditional method.

xi. Mathematics: Compulsory in all classes of this level.

xii. Geography: It is taught upto class VIII.

xiii. General Science: It is compulsory in all stages.

N.B.: This is also taught in some Madarasah's but not as a compulsory course.

Higher Secondary Level (2 years, year of 11th \& 12th) [This stage is known as Alim]

The curriculum of this level includes the following courses:

i. Tafsir: It is taught in both classes with due importance but following the traditional and translation methodology.

ii. Hadith: Some selected portion of Hadith are taught following the translation methodology.

iii. Arabic Literature: This is also compulsory but taught in traditional methodology.

iv. Arabic Grammar: Compulsory in both classes but no importance is given on functional approach.

v. Bangla: Compulsory as National Language. 
vi. Fiqh: Compulsory in both the classes.

vii. Usul al-Fiqh: Compulsory but taught in traditional method.

viii. Ilmul Balaghah: Ilmul Balaghah or Rhetoric is also taught in this level.

ix. History: Sirah of the Prophet is taught as History.

Apart from the courses mentioned above some other courses are also taught as elective or to the students of Science group. These are: (a) Mathematics; (b) Physics; (c) Chemistry; (d) Biology etc.

\section{Degree Level (2 years, year of 13th \& 14th) [Known as Fadhil]}

The syllabus of this stage includes as follows: The Examination is held on 1000 marks on completion of 14 years schooling.

i. Tafsir: Compulsory.

ii. Usul al-Tafsir: Compulsory.

iii. Hadith: Some selected portions of Hadith are taught.

iv. Usul al-Hadith: Some basic principles regarding methodology of criticizing the authenticity of Hadith are taught in this course.

v. Arabic Literature: Some selected Text books on Arabic are taught as compulsory subject (200 marks).

vi. English: As optional subject English is included in the syllabus (but most of the students tend to choose this)

vii. Islamic History: Taught as compulsory.

viii. Ilmul Kalam: Taught as compulsory.

ix. Ilmul Balaghah: Taught as compulsory.

Specialization (2 years, year 15th \& 16th) [Known as Kamil, offered for specialization in Hadith, Tafsir or Fiqh]

The syllabus of this stage includes as follows: The examination is held at the end of the year 16th years schooling and on 1000 marks.

i. Hadith: It includes six authentic anthologies of the Hadith known as Sihah (500 marks).

ii. Usul al-Hadith: (100 marks).

iii. Tafsir \& Usul al-Tafsir (200 marks): Kashshaf and Baidawi are 
taught here.

iv. Islamic History: Two papers on Islamic History are to be taken each paper comprising 100 marks each.

It is to be mentioned that though the curriculum of the Madrasah Education System is identified as close to an Islamic Education Policy but this is not the curriculum of general stream. Only 20\% students in Bangladesh are getting their education following this system. The remaining $80 \%$ are undergoing the general stream of education, which is secular in nature and contains the mains characteristics of the education policy of British Rule with some changes in curruculum and fields of specialization according to the needs of the day. On the other hand, though the characteristics of the Madrasah Education System are Islamic in nature but it has failed to meet the requirements of present days due to being an incomplete system. However, it bears in itself some potentialities to be restructured in such a way which is in line with the recommendation of the OIC's International Conference on education held at Makka in 1977 and that of the follow up programs held at Islamabad in 1980, at Dhaka in 1981, at Jakarta in 1982, in KL in 1983, at Cairo in 1987 and at Nigeria in 1996. And as such, I shall try to place here a proposal for a curriculum of Integrated Islamic Education System for Bangladesh, in line with the recommendations made by the World Conference on Islamic Education in 1977 and other follow up programs. Some important recommendations which are made by the World Conference on Islamic Education held at Makka in 1977 are as follows:

a) To introduce an integrated and unified Islamic Education Policy for the whole Muslim World replacing the existing dual education system.

This policy shall be an Islamic in character in onehand and shall have provisions for creating specialized in different fields of discipline on the other. Emphasis will be given on Science and Technology after ensuring the Islamic character of the policy. (17)

As we have mentioned earlier that some follow up conferences were held in different countries like Islamabad, Dhaka, Jakarta, Malaysia, Cairo and Nigeria but a few countries have shown interest in implementing the recommendations of these conferences, Bangladesh is one of those countries which did not pay proper attention to implement the recommendation of this conference. This is why in spite of having a potential Islamic education system in Bangladesh like 
Madrasah Education, this country has taken no meaningful step for introducing an Integrated Islamic Education Policy. What it seems to do is to recognize the Madrasah Education system at par with that of general stream in respect of equivalence of certificates. I do believe that the existing Madrasah Education system of Bangladesh preserves in itself some characteristics which can be used as the foundation for framing an Integrated Islamic Education Policy as recommended in the Makkah Confernce of 1977.

\section{The Characteristics of an Islamic Education Policy:}

An Islamic Education Policy should inevitably contain the following characteristics:

i) This policy should essentially provide the answer to three most basic questions of cardinal importance related tohuman being, the correct answer of which count not be given by anyone of the philosophers nor the scientists nor by the sociologists excepting the prophets of Allah (swt). These questions are:

(a) Who?

(b) Why? and

(c) Where?

Who is related to the origin of the existence of human being. Different answers have been given to this question, but the only correct answer is that the $1^{\text {st }}$ human being was created from the clay by Allah Himself as the best of all creatures (ashraful makhluqat) and His vicegerent on the earth, and that all other mankind are the offsprings of this $1^{\text {st }}$ human being.

Why is related to the purpose of creating the mankind. The correct answer to this question is that the human being is created for the purpose of servitude to Allah alone and to discharge the duties of a vicegerent of Allah.

Where: is related to that ultimate destination of human being. The correct answer of this question is that this life is not only life of human being, there is a life hereafter wich is the ulmimate destination of them. It is eternal and endless.Each and everybody will be accountable to Allah in the life hereafter for each and every activity of this life good or bad.

ii) This policy should have option and opportunity for specialization in 
any of the fields of Islamic disciplines to those who are interested therein.

iii) The opportunities for getting specialization in any of the fields of Arts and Humanities, Social Sciences, Modern Sciences and Technology, Medicine or Business Studies should be provided for those who are interested therein.

If we analyse the Madrasah education system of Bangladesh, we shall find that the first and foremost of the characteristics of an ideal Islamic Education (i.e. the basic Islamic Knowledge which are required for leading the life of a true Muslim) though some lackings are remaining therein but they are rectifyable.

But this system has failed to a great extent in fulfilling the second characteristic, because this is an incomplete system. No provision has been kept open to a student of Madrasah for furthering his education after a certain stage. So far the compliance of third characteristic is considered, some of the education commissions have made some recommendations for taking steps to reform Madrasah Education System, so that it can comply the needs of the day, and opportunities are kept for the students to choose some other fields of study as they wish. However, this is not a very tough task which is unattainable.

On the other hand if we look at the general education system we can see that the general education policy has completely failed to meet the first and second characteristic and possesses no possibility for undergoing this kind of changes in Bangladesh for two reasons: (i) A large number of the people are of secular nature. They are not ready for accepting any change towards Islamizing the education policy. So whenever, any step shall be taken in this way, they shall create hue a cry against this. (ii) around 15\% of the citizens are non-Muslims. They will raise objection against introducing an Islamic Education Policy in the country on the plea of racism, whereas any change in the existing Madrasah Education System will create no problem. Because it will happen in the name of updating and modernization as per recommendations of different Education Commission reports and the recommendations of OIC's International Conference on Islamic Education which wll rather be appreciated by all. 
How to get the Existing Madrasah Education System Restructured.

Here I would prefer to propose for restructuring the Madrasah Education system in two ways:

Firstly: Through restructuring the exsiting levels of study as follows:

i. Primary Level (7 years): one year pre-primary and six years of primary schooling.

ii. Lower Secondary Level (3 years): It will consist of three years of schooling i.e. class VII to class IX.

iii. Higher Secondary Level (3 years): It will consist of three years of schooling i.e. class X to class XII.

iv. Undergraduate Level (4 years): It will consist of four years of schooling i.e. from 1st year to 4th year of Undergraduate program. A student shall obtain a Bachelor's Degree upon completion of this level.

v. Graduation Program (2 years): It will consist of two years of Graduation program. A student shall get Master's degree on completion of this stage.

vi. Post Graduate Program (2 to 5 years): Two to five years. This is a specialization program for only those students who want to continue their study and research for obtaining an M.Phil or Ph.D. degree in a particular field of study.

N.B.: The stages like Ibtidai, Dakhil, Alim, Fadhil and Kamil which are existing at present shall cease to exist.

Secondly: The existing curriculum should be replaced with a new set of integrated curriculum, which will be Islamic in nature in one hand and comprehensive on the other, with an objective to make it eligible for implementing by any of the Muslim countries.

\section{An Overview of this Curriculum has been prescribed as follows:}

1. Primary Level $(1+6=7$ years):

The curriculum of this level includes:

i. Al-Qur'an with Tajwid: It will start from the 1st year of schooling beginning from introducing the students with Arabic Alphabets, its correct pronunciation, with an objective of giving the students the skill of independent and correct recitation of the Holy Qur`an. In the later stage of this level the students shall 
have to memorize some parts of the Qur`an and shall also have the ability to recite the Qur`an complying the rules of Tajwid.

ii. Diniyat \& Training on Salat: It will begin from the 1 st year of schooling and continue upto class III. The objective of this course is to make the students habituated to offer their prayer correctly. Some basic Surahs and other Du'as related to Salat shall be taught.

iii. Aqaid \& Fiqh: It will begin from class-I and continue in each class of this level. The objective of this course is to provide correct idea regarding Tawhid, Risalah, Akhirah and other important issues related to purity of belief, Fiqh includes basic Masa il related to Taharah, Salat, Zakat, Sawm, Hajj, Fard, Wajib Sunnah and Halal, Haram Makruh etc.

iv. Arabic Language: It will start from class III and continue as a compulsory subject upto the end of Secondary. It is to be mentioned that the students of this class have already obtained the skill of reading Arabic independently through practices on recitation of the Holy Qur`an in class I \& II. Here the course will start from giving them knowledge of basic Arabic vocabulary \& understanding simple sentences, and it will gradually advance towards giving the students the four skills of language. Arabic Grammar: Arabic Grammar may be taught starting from class V in Arabic speaking countries but in non-Arabic speaking countries Arabic Grammar should not be taught separately at this stage. However, the books on Arabic Language should contain lessons on Functional Grammar.

v. National Language: National Language should be included in the curriculum beginning from KG upto the end of Higher Secondary Level. (It is Bangla, in case of Bangladesh.)

vi. English: It is a must as an important International Language

vii. English Grammar: It should be taught in functional method from class IV and above.

viii. Mathematics: It shall be a compulsory subject in all classes of Primary stage, beginning from introduction to the numericals shall develop gradually considering the standard of the students and their ability.

ix. Environmental Science (Introductory): Books on environment shall be included in the syllabus of class IV and shall continue 
upto class VI. The objective of this course is to make the students acquainted with their surroundings and the Universe and also about some matters and means created by Allah (S.W.T.) for the greater benefit of the mankind. The curriculum of class VI shall continue lesson on family, society, state, and basic idea about the country and its historical religious and cultural background.

x. Geography: The syllabus of Primary level shall include books on Geography in Class V \& VI with an objective to give the students an idea about the geographical situation of his country, its resources, products and prospects. And a general idea about the global and geo-political situation of other countries.

\section{N.B.:}

The medium of instruction should be the native language. However, it may be English or any of other International Languages in some specific situations. A Public Examination will be held at the end of this level. It will be optional.

\section{Lower Secondary Level:}

\section{The Curriculum of this level includes:}

i. Qur'an: The translation of the Qur'an should be taught in each class of this level. At least six parts of the Qur'an shall be included from Suratul Fatiha to Suratul An'am in the curriculum. Practicing correct recitation shall also continue in this level.

ii. Hadith: The Prophetic Hadith being the 2nd source of Islamic Shari ah should be taught through translation and explanation thereof. At least forty Hadiths should be included in the syllabus of each class of this level.

iii. Arabic Language: Arabic language shall be taught in each class of this level as a compulsory subject. Emphasis should be given on functional approach of language teaching.

iv. Arabic Grammar: Arabic Grammar shall be taught in each class of this stage as a compulsory course. Emphasis should be given on functional approach of Grammar teaching.

v. 'Aqaid \& Fiqh: The course will be compulsory at this level and books will contain on more detailed and developed discussion on the issues of the Tawhid and its demands. Risalah and its 
importance, discussion on Shirk, Bid`ah etc. More detailed books on Fiqh shall also be taught.

vi. National Language: It will be compulsory at all classes of this level. Books on Grammar shall also be taught according to the standard of the students.

vii. English: It will be considered a compulsory subject for the seasons mentioned earlier.

viii. English Grammar: This will be taught in functional approach.

ix. Mathematics: It is compulsory at all classes of this level. The syllabus will be prepared as per suitability and standard of the learners.

x. Biography of Prophet (s.a.w.): It is a compulsory subject in each class of this level. The objective of the course is to get students acquainted with the life of the Prophet (s.a.w.) and the history of the four pious caliphs of Islam.

xi. General Science: This will be a compulsory subject to be taugt at the lower secondary level.

\section{N.B.:}

A compulsory Public Examination will be held at the end of this level, which will be called Secondary Certificate Examination or Lower Secondary Certificate Exam. The examination will held on 1000 marks, evaluation will be done under grading system.

\section{Higher Secondary Level:}

\section{The curriculum of this level includes:}

The courses under this level will be divided into two groups. (i) Compulsory Subjects (ii) Elective Subjects. Six subjects are to be taken as compulsory. Each subject is of 100 marks. These are as follows:

i. Al-Qur'an: The syllabus of al-Qur'an includes at least nine parts of the Qur'an (i.e. from Suratul A'raf to Suratul Isra). The Qur'an will be taught through translation, explanation and lessoins of these for implication in our life and society.

ii. Hadith: At least 300 Hadiths shall be included in the syllabus of this level (i.e. 100 Hadiths in each class). Those Hadiths will get preference which may contribute more to shape the character of the students, and give an ethical orientation. 
iii. Arabic Language \& Grammar: Emphasis will be given on functional approach in teaching language and grammar.

iv. National Language \& Grammar: It is a compulsory course in each class of this level. Grammar is part of this course. The syllabus of each class will be prepared according to the standard of the students.

v. English Language \& Grammar: Emphasis shall be given on functional approach of language teaching. The syllabus will be prepared considering the standard of the students. It is also a compulsory course at this level.

vi. Computer Literacy: Three courses on computer shall be offered in each of these three classes. The students shall choose another six courses as elective subjects i.e. they will choose any of the following groups according to their interest and preference.

These are:

(a) Religious Studies Group (b) Business Studies Group (c) Science \& Technology Group (d) Social Science Group etc.

The curriculum of Religious Studies Group includes:

(i) Fiqh (ii) Usul al Fiqh (iii) Arabic Literature (iv) Ilmul Balagah (v) Faraid (vi) Ulumul Qur`an/Hadith

The curriculum of Business Studies Group includes:

(i) Mathematics (ii) Economics (iii) Accounting (iv) Book Keeping (v) Business Law \& Ethics (vi) Introduction to Management (vii) Computer Programming (any six)

The curriculum of Science \& Technology Group includes:

(i) Mathematics (ii) Advanced Mathematics (iii) Physics (iv) Chemistry (v) Biology (vi) Computer Programming (vii) Geography (viii) Statistics (any six)

The curriculum of Social Science Group includes:

(i) Economics (ii) Civic (iii) Sociology (iv) Home Economics (v) History (vi) Islamic History (vii) Geography (viii) Computer Programming (any six) 
N.B.:

A compulsory Public Examination consisting of 1200 marks entitled Higher Secondary Certificate Examination will be held at the end of this level. The evaluation of examination result will be done on the basis of Grading System.

\section{Undergraduate Level:}

This is a degree course of four years duration offered by a University or a college of higher reputation affiliated to a University. The choice for the students will be open according to their interest and aptitude. In this level a student shall further his studies under a four year's duration Undergraduate program in any of the disciplines related to Shari`ah, Qur`anic Sciences, Hadith Sciences, Comparative Religion, Arabic Literature, Muslim Philosophy, Islamic History, Law, Business Studies, Economics, Political Science, English Language \& Literature, Computer Science, Communication Engineering, Information Technology, Medicine or Engineering etc.

I am not going into the details of the curriculum of this level. However, some salient features of the curriculum are given below:

The curriculum will be integrated one which includes 10\% - 15\% related to Islamic Studies and History of Islam, 10\% related to Arabic \& any other foreign language, $15 \%$ Inter Disciplinary courses and the rest $60 \%-65 \%$ related to the field of specialization. The program will be offered on credit hours basis and the evaluation will be made on Grade Points basis and the course distribution will be done under the Semester System. A student may require taking 120 to 160 credits of different courses for graduation, depending on the nature of program.

The best example of an integrated curriculum at Undergraduate Level is that the International Islamic University Malaysia (IIUM), International Islamic University Islamabad (IIUI), International Islamic University Chittagong (IIUC) and some other Islamic Universities established on this model. Any of the Universities may offer some of the above mentioned programs of Undergraduate Studies or many of them according to their ability and availability of facilities.

\section{Master Degree Program:}

The Master's program is of three to five Semesters' duration. This will be offered to those who wish to acquire specialized education in any of the disciplines of his interest. This will be usually a combination of 
course work and thesis, consisting of 36 to 60 credits depending on the nature of program, the requirements thereof and the background of the students. The details of curriculum shall be prepared by the competent authority of the University in line with the opportunities available there.

\section{M.Phil Or Ph.D Program:}

M.Phil or Ph.D Program are considered very high level specialized program, it shall be offered by those Universities where very competent supervisors are available with reputed scholarship in the relevant field. The program may be exclusively research based or a combination of course work and research, depending on the University's policy and the nature of the study and the researcher. Detailed curriculum will be prepared by the competent authority of the degree offering University.

\section{References:}

1. In this regard the verses $1-5$ of Chapter No. 96 of the Holy Qur`an may be referred.

2. Please refer to verse no. 2 of Chapter 62.

3. A Brief History of Education System (Bengali), Islamic Education Society, Dhaka, 1999, p-49.

4. See for more details "The Education and Tarbiyah System of the Muslims in India and Pakistan (Urdu) by Professor Syed Muhammad Salim, Lahore (3 Edition), 1993.

5. A Brief History of Islamic Education System (Bangla) p-37

6. Ibid, p 37-39

7. Ibid, p 39

8. Ibid, p 39-41

9. Ibid, p 41

10. For details: The Education and Tarbiyyah System of the Muslim in India, OP Cit, p 73

11. For details: Please refer to "The Education and Tarbiyyah Policy of the Muslim of India (Urdu), op. cit. p 108-116

12. Ibid

13. Ibid (reproduced from Urdu), p 116-117

14. Ibid, p 119-120 
IIUC Studies, Vol. 9

15. This is the reproduction of his comment in my own language.

16. For more details please see 'Bangladesh School O Madrasah Shikshaniti O Patthyakrom (The Education Policy and Curriculum of Schools \& Madrasahs of Bangladesh) by Prof. Dr. A.K.M. Azharul Islam and others. The Islamic Academy, Cambridge, 2003, p 162-187

17. Please see the recommendations of the World Conference on Muslim Education of Makka, 1977. 